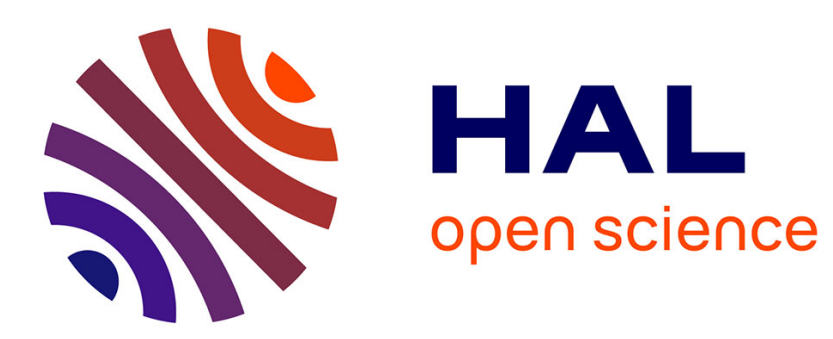

\title{
Studies of the Oxidation Mechanism of Yttrium Implanted Chromium Using XAFS and GAXRD
}

\author{
P. Gibson, M. Cristóbal, M. Stroosnijder
}

\section{To cite this version:}

P. Gibson, M. Cristóbal, M. Stroosnijder. Studies of the Oxidation Mechanism of Yttrium Implanted Chromium Using XAFS and GAXRD. Journal de Physique IV Proceedings, 1997, 7 (C2), pp.C2-1205-

C2-1206. 10.1051/jp4:19972195 . jpa-00255266

\section{HAL Id: jpa-00255266 https://hal.science/jpa-00255266}

Submitted on 1 Jan 1997

HAL is a multi-disciplinary open access archive for the deposit and dissemination of scientific research documents, whether they are published or not. The documents may come from teaching and research institutions in France or abroad, or from public or private research centers.
L'archive ouverte pluridisciplinaire HAL, est destinée au dépôt et à la diffusion de documents scientifiques de niveau recherche, publiés ou non, émanant des établissements d'enseignement et de recherche français ou étrangers, des laboratoires publics ou privés. 


\title{
Studies of the Oxidation Mechanism of Yttrium Implanted Chromium Using XAFS and GAXRD
}

\author{
P.N. Gibson, M.J. Cristóbal and M.F. Stroosnijder \\ Institute for Advanced Materials (Ispra Site) Joint Research Centre of the European Commission, \\ 21020 Ispra (VA), Italy
}

\begin{abstract}
The first stages of the oxidation of yttrium implanted chromium have been examined using EXAFS at the yttrium and chromium K-edges. Initially a thin chromia layer forms on the surface, and the implanted yttrium rapidly oxidises to form nanocrystallites of yttria. Upon further oxidation some yttrium is incorporated into the chromia scale, probably at the grain boundaries. The local atomic structure around these yttrium ions resembles that of $\mathrm{YCrO}_{4}$.
\end{abstract}

\section{INTRODUCTION AND EXPERIMENTAL DETAILS}

The active element effect is a well known effect whereby the addition of elements such as yttrium or cerium to chromia or alumina forming alloys increases the 'protective quality' of the scale in various ways. Many mechanisms have been proposed to explain this phenomenon, but as yet there is little agreement as to which mechanism or mechanisms are responsible [1]. Here we present an EXAFS investigation of the initial stages of oxidation of yttrium implanted chromium, concentrating on identification of the oxide phases which initially appear on or near the surface of the material. Ion implantation of polished chromium substrates was performed at an energy of $180 \mathrm{keV}$ to a total dose of $10^{17}$ ions. $\mathrm{cm}^{-2}$. Oxidation treatments in air of the implanted samples were carried out by either heating the sample rapidly to a particular temperature and then withdrawing it for analysis, or by heating the sample to $800^{\circ} \mathrm{C}$ and holding it at that temperature for a certain amount of time. Fluorescence detected EXAFS at the K-edge of the yttrium was recorded at an incidence angle of about $2 \phi_{\mathrm{c}}$ corresponding to a penetration depth in chromium of about $150 \mathrm{~nm}$, while ReflEXAFS spectra at the chromium K-edge were recorded at $\phi_{c} / 2$ by use of a detector in the reflected beam. A variety of other characterisation techniques have been used in the analysis of these samples, and the results are presented elsewhere [2,3]. Here only the EXAFS simulations and fits are discussed.

\section{RESULTS}

Fig. 1 illustrates the EXAFS simulations at the yttrium K-edge for the reference oxide and for the sample oxidised for 60 min. at $800^{\circ} \mathrm{C}$, while table 1 lists the phase relation for all the oxidised samples (identified by maximum temperature and exposure time). The shell parameters required for these simulations are reported elsewhere [2,3]. These indicate that upon heating to $400^{\circ} \mathrm{C}, \mathrm{Y}_{2} \mathrm{O}_{3}$ is already formed in the yttrium implanted chromium samples, probably throughout the implanted region. The coordination numbers in the case of the $400^{\circ} \mathrm{C}$ sample are significantly lower than that of the reference powder, and in general the coordination number decreases with increasing shell number, indicating a nanocrystalline structure, and a possibility that a fraction of the yttrium is not incorporated in crystalline phases. In a previous work [2] the nanocrystalline structure of the $\mathrm{Y}_{2} \mathrm{O}_{3}$ has also been analysed with GAXRD. The results indicate that the average grain size increases from $2.5 \mathrm{~nm}$ to $4.5 \mathrm{~nm}$ by increasing the temperature from $400^{\circ} \mathrm{C}$ to $600^{\circ} \mathrm{C}$.

Table 1: Approximate phase relation for all the oxidised samples.

\begin{tabular}{|l|c|c|}
\hline Sample & $\mathbf{Y}_{2} \mathbf{O}_{3}$ & YCrO \\
\hline $400^{\circ} \mathrm{C} /$-min & nano & $\cdots-$ \\
\hline $600^{\circ} \mathrm{C} /$-min & nan $50 \%$ & nan $/ 50 \%$ \\
\hline $800^{\circ} \mathrm{C} /-\min$ & $50 \%$ & $50 \%$ \\
\hline $800^{\circ} \mathrm{C} / 2 \min$ & $50 \%$ & $50 \%$ \\
\hline $800^{\circ} \mathrm{C} / 60 \min$ & $34 \%$ & $66 \%$ \\
\hline $900^{\circ} \mathrm{C} /$-min & $34 \%$ & $66 \%$ \\
\hline
\end{tabular}
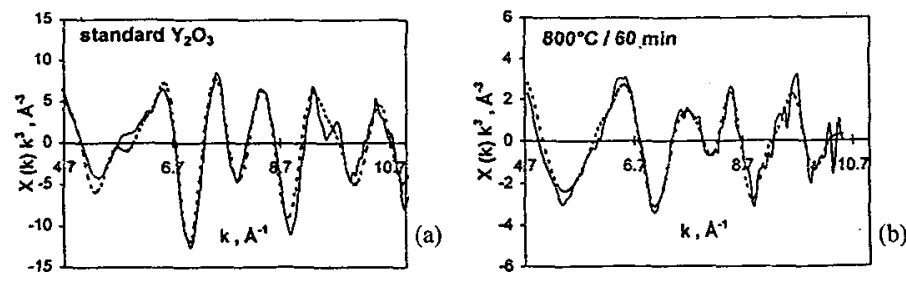

Fig.1: Experimental (solid line) and fitted (dotted line) EXAFS spectra for : (a) $\mathrm{Y}_{2} \mathrm{O}_{3}$ and (b) the sample heated $800^{\circ} \mathrm{C} / 60 \mathrm{~min}$.

The EXAFS results also show that above $400^{\circ} \mathrm{C}$ the fitting of the spectra could not be carried out assuming only the presence of $\mathrm{Y}_{2} \mathrm{O}_{3}$. Thus the possible presence of other structures, such as $\mathrm{YCrO}_{3}$ and $\mathrm{YCrO}_{4}$, was taken into consideration for the fitting 
procedure. Due to the absence of suitable reference compounds the accuracy in the local structure parameters is worse than those for the $\mathrm{Y}_{2} \mathrm{O}_{3}$ phase. However, the spectra for all samples which were heated above $400^{\circ} \mathrm{C}$ could be fitted successfully assuming the presence of both the $\mathrm{Y}_{2} \mathrm{O}_{3}$ and $\mathrm{YCrO}_{4}$ structures. $\mathrm{YCrO}_{4}$ was not however identified in $\mathrm{GAXRD}$ analysis, and we believe that the identification of such a local atomic structure around yttrium is due to the fact that this structure represents the local atomic structure around yttrium at chromium oxide grain boundaries. The segregation of yttrium to these grain boundaries is a phenomenon which has been observed by several authors. The EXAFS spectra obtained for the sample heated to $900^{\circ} \mathrm{C}$ and that which was exposed for $60 \mathrm{~min}$. to $800^{\circ} \mathrm{C}$ were rather similar. The fitting of these spectra (table $\mathrm{I}$ ) indicate that the coordination numbers for the $\mathrm{Y}_{2} \mathrm{O}_{3}$ decrease and those of $\mathrm{YCrO}_{4}$ increase with temperature from $800^{\circ} \mathrm{C}$ to $900^{\circ} \mathrm{C}$ as well as with longer exposure time at $800^{\circ} \mathrm{C}$. The analysis of the yttrium K-edge XANES [2] corroborates the EXAFS conclusions : the more oxidised samples displayed an edge shift to lower absorption energies indicating that the average oxidation state of the yttrium must be less than +3 . The oxidation state in the $\mathrm{YCrO}_{4}$ is +2 , while in $\mathrm{Y}_{2} \mathrm{O}_{3}$ and $\mathrm{YCrO}_{3}$ it is +3 [4]. The presence of a second yttrium containing phase has been additionally checked by a comparative study with $X$-ray fluorescence [3] and supports the EXAFS and XANES conclusions.

Table 2: Coordination numbers for the six first shells for the reference oxide and for the sample heated to $600^{\circ} \mathrm{C}$ and $800^{\circ} \mathrm{C}$.

\begin{tabular}{|c|c|c|c|}
\hline $\begin{array}{c}\text { Shell } \\
\text { No }\end{array}$ & $\mathrm{C}_{2} \mathrm{O}_{3}$ & $600^{\circ} \mathrm{C}$ & $800^{\circ} \mathrm{C}$ \\
\hline \hline $1(\mathrm{O})$ & 3 & 2.5 & 3 \\
$2(\mathrm{O})$ & 3 & 1.7 & 3 \\
$3(\mathrm{Cr})$ & 1 & 0.5 & 1 \\
$4(\mathrm{Cr})$ & 3 & 1.4 & 3 \\
$5(\mathrm{O})$ & 3 & -- & 3 \\
$6(\mathrm{Cr})$ & 3 & 1.3 & 3 \\
\hline
\end{tabular}
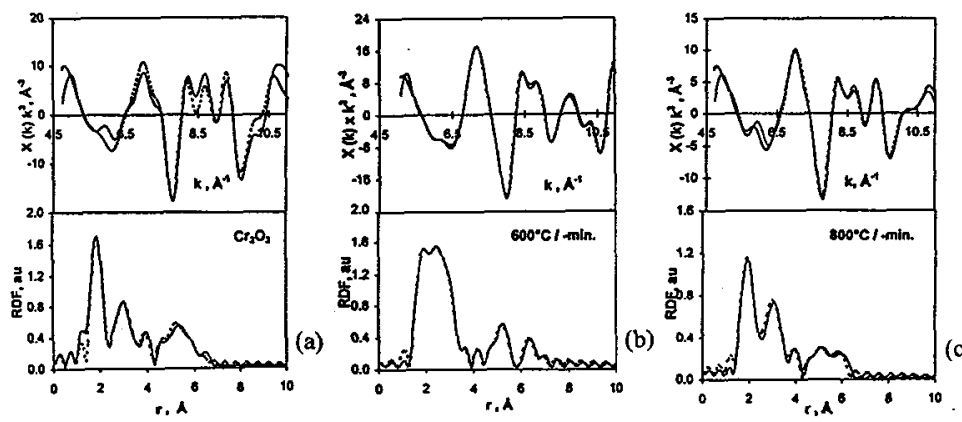

Fig. 2 : Fourier filtered experimental (solid line) and fitted (dotted line) EXAFS spectra and Fourier transforms for (a) $\mathrm{Cr}_{2} \mathrm{O}_{3}$ and the samples heated at (b) $600^{\circ} \mathrm{C}$ (c) $800^{\circ} \mathrm{C}$.

Characterisation of the outer surface of the yttrium implanted chromium samples has been carried out with X-ray absorption at the chromium K-edge. The spectra were recorded in the reflectivity mode at an incident angle of $1 / 2 \phi_{\mathcal{C}}$, so only the outer few nanometers contributed to the EXAFS spectra. The EXAFS results (Fig. 2 and table 2) show that nanocrystalline $\mathrm{Cr}_{2} \mathrm{O}_{3}$ is already formed at $600^{\circ} \mathrm{C}$ (this simulation also included a contribution from the chromium substrate) although is not possible to observe this oxide in the GAXRD spectra until $800^{\circ} \mathrm{C}$ [2]. At $800^{\circ} \mathrm{C}$ the outer oxide layer is entirely $\mathrm{Cr}_{2} \mathrm{O}_{3} . \mathrm{Again}$ these results are in concordance with previous GAXRD results [2] which showed that the chromia is present on the outer surface, whereas the $\mathrm{Y}_{2} \mathrm{O}_{3}$ phase is mainly located beneath the oxide/metal interface, probably throughout the bulk of the implanted zone.

\section{CONCLUSIONS}

It was found that the implanted yttrium rapidly oxidises to form nanocrystalline $\mathrm{Y}_{2} \mathrm{O}_{3}$, while the first oxide phase to appear on the surface is $\mathrm{Cr}_{2} \mathrm{O}_{3}$. EXAFS examinations show that part of the yttrium in the samples heated above $400^{\circ} \mathrm{C}$ is present in a structure other than that of the $\mathrm{Y}_{2} \mathrm{O}_{3}$ phase. This structure could be described by an atomic environment very similar to that of $\mathrm{YCrO}_{4}$. The relative amount of yttrium present in the structure of $\mathrm{YCrO}_{4}$ relative to $\mathrm{Y}_{2} \mathrm{O}_{3}$ increases with increasing temperature and exposure time. The $\mathrm{YCrO}_{4}$ is believed to represent the structure around the yttrium segregated to the oxide grain boundaries of the $\mathrm{Cr}_{2} \mathrm{O}_{3}$ which has been reported in several TEM studies. The authors believe that due to the presence of yttrium, with a local structure similar to $\mathrm{YCrO}_{4}$, at the grain boundaries the anion and cation transport rates along grain boundaries are changed, thus influencing the overall oxidation kinetics as well as the morphology of the oxide scales, as has been reported in a parallel work [5].

The authors wish to acknowledge the use of the CCLRC Daresbury Syncrotron Radiation Source under the Large Scale Facilities Programme of the European Commission.

\section{References}

(1) J. Stringer, Mater. Sci. Eng., A 120, (1989) 129-137

(2) M.J. Cristóbal, P.N.Gibson, and M.F. Stroosnijder, Corros. Sci., 38, 6, (1996) 805-822

(3) M.J.Crist 6 bal, Ph.D. Thesis, Complutense University of Madrid (1996)

(4) ICSD Data Base, CCLRC Daresbury Laboratory.

(5) M.F. Stroosnijder , J.D. Sunderkötter, M.J. Cristóbal, H. Jenett, K. Isenbügel and M.A. Baker, Surf. and Coat. Techn., (1996) 